\title{
Alternative medicine and prostate cancer benefit from largest ever NIH increase
}

The US Congress has approved the largest ever increase in funding for the National Institutes of Health (NIH) - a whopping 15 percent raise that takes the FY99 budget to $\$ 15.6$ billion. The increase means that the NIH is on track to double its budget by 2003. NIH Director Harold Varmus says that the additional $\$ 2$ billion will mean "more of everything: more grants, and a lot of new initiatives." In particular, the increase will mean more research into prostate cancer and alternative medicine.

It is widely recognized that persistent and aggressive lobbying to increase support for biomedical research was responsible for the substantial increase. "We have very strong advocacy on our behalf from a wide number of constituents," Varmus told Nature Medicine. He said that he also appreciated that Congress largely resisted its usual urge to earmark money for specific studies and designated academic centers. "Having the budget carved up like that is a very bad thing to do," said Varmus, and added, "but we always listen to their guidance." Such guidance this year included several strong recommendations.

The first was that NIH make prostate cancer research a high priority. The FY99 Omnibus Appropriations bill states that "spending for prostate cancer research over the years has not kept sufficient pace with the scientific opportunities and the proportion of the male population who are afflicted with this disease," and calls for accelerated spending in this field. Within the next six months, the NIH must present a report to Congress outlining plans for prostate cancer research over the next five years.

Another recommendation was that the institutes develop a full-scale initiative to find ways to prevent Alzheimer disease in those who may have a familial predisposition to it.

While Congress "urged" NIH to act on these and other recommendations it did take one, more specific, action: to elevate the small Office of Alternative Medicine (OAM) to a Center-a move typically regarded as one step before becoming an Institute. In addition to its heightened status, the OAM will receive a $\$ 50$ million budget, more than doubling its existing funds of $\$ 20$ million, and an astronomical rise since its inaugural FY92 appropriation of $\$ 2$ million. Of the new budget, not less than $\$ 20$ million must be spent on peer- reviewed research grants.

Tom Harkin (Dem., Iowa) a wellknown believer in alternative medicine, who was responsible for establishing the OAM through a congressional mandate in 1991, was also behind the FY99 OAM changes. And as if to reinforce the virtual re-birth of alternative medicine within $\mathrm{NIH}$, it must change its name to the National Center for Complementary and Alternative Medicine (NCCAM). Incumbent director Wayne Jonas will leave the center at the end of this month to return to the army having completed his threeyear military detail, and his replacement is expected to be announced on January 1 st 1999.

In fact, NCCAM is a shining example of how acutely tuned Congress is to the mood of the public when making spending decisions. According to a study published last month (JAMA 280, 1569; 1998), four out of 10 Americans used alternative medicine therapies in 1997 and visits to alternative medicine practitioners have increased by 50 percent from 1990, now exceeding visits to all primary care physicians. Moreover, Americans spend around $\$ 21.2$ billion on services provided by alternative practitioners.

Despite the presence of alternative medicine within the Office of the Director on the Bethesda campus, many believe that Varmus and other NIH officials merely tolerate work in this area and

\section{German coalition overlooks biomedical science}

A "doubling of investments in the future" was one of many promises made by Germany's Social Democratic Party (SDP) before their landslide victory in the October election. Yet four weeks later, neither public health nor R\&D were among the top priorities in the coalition treaty signed by Helmut Kohl's successor Gerhard Schroeder. Pre-election pledges of doubled investment have withered to "clear increases."

The treaty, intended to serve as Germany's political road map into the next millennium, focuses naturally on the most serious problem that faces the country-unemployment. But although "sustainable economic growth by innovation" is a phrase used throughout the are reluctant to embrace it alongside traditional biomedical research. But Varmus dispelled such rumors. "Two years ago I'd have been unhappy about this [mandate], but now we're ready for it," Varmus said. "We know what needs to be done in the area of high quality research. We are setting up this new center, and we're recruiting a new director. We want to get someone open-minded, but also a skilled clinical trialist who understands how you test therapies."

All of the NIH institutes will share the $\$ 2$ million bounty. Each gets a minimum 10 percent raise, but the biggest institutes come out ahead: these include the National Cancer Institute (15 percent increase); the National Human Genome Research Institute (22); and the National Institute of Allergy and Infectious Diseases (16).

NIAID director, Anthony Fauci, said that his institute would focus more resources on the problems of emerging microbes, tuberculosis and malaria. It also plans to draft a major initiative on immunological tolerance, with specific applications to organ transplantation. Other areas include autoimmune diseases, HIV vaccine development, and protection against bio-terrorism.

"It's hard to start a lot of programs in one year, but I think we can do it," said Varmus.

Karen Birmingham, New York \& Marlene Cimons, Washington, D.C.

document, nowhere is it linked to R\&D, a coupling that governments of other developed nations see as a route to economic prosperity. The treaty makes no mention of financial commitments to the Ministry of Science and Education headed by Edelgard Bulmahn (SDP) or to the Ministry of Health under the direction of Andrea Fischer (Green Party).

Nevertheless, optimism prevails at Germany's basic research grant agency, the Deutsche Forschungsgemeinschaft (DFG). Bulmahn has served as chair for the parliament's Science committee in recent years, and is seen as "competent and knowledgeable," according to DFGspokeswomen Eva Streier.

On Bulmahn's appointment, the head 